Jurnal Keperawatan Silampari

Volume 5, Nomor 1, Desember 2021

e-ISSN: 2581-1975

p-ISSN: 2597-7482

DOI: https://doi.org/10.31539/jks.v5i1.2626

\title{
PENGEMBANGAN MEDIA PEMBELAJARAN MODELING MELALUI VIDEO DALAM PENINGKATAN KEMAMPUAN TOILET TRAINING PADA ANAK TUNAGRAHITA
}

\author{
Ima Sukmawati ${ }^{1}$, Elis Noviati ${ }^{2}$ \\ Sekolah Tinggi Ilmu Kesehatan Muhammadiyah Ciamis ${ }^{1,2}$ \\ imasukma90@gmail.com ${ }^{1}$
}

\begin{abstract}
ABSTRAK
Penelitian ini bertujuan meningkatkan kemampuan toilet training pada anak tunagrahita melalui modeling video. Metode penelitian menggunakan pre-experiment design dengan rancangan one group pre-test dan post-test. Hasil penelitian didapatkan pengaruh modeling media video terhadap kemampuan toilet training anak tunagrahita dengan selisih peningkatan rata-rata sebesar 1,59 . Uji Wilcoxon menunjukan p-value 0,001 . Simpulan, terdapat pengaruh modeling media video terhadap kemampuan toilet training anak tunagrahita.
\end{abstract}

Kata Kunci: Anak Tunagrahita, Modeling Media Video, Toilet Training

\section{ABSTRACT}

This study aims to improve the ability of toilet training in mentally retarded children through video modeling. The research method used a pre-experimental design with a one-group pre-test and post-test design. The results showed the effect of video media modeling on the toilet training ability of mentally retarded children, with an average increase of 1.59. The Wilcoxon test shows a p-value of 0.001. In conclusion, video media modeling has an effect on the toilet training ability of mentally retarded children.

Keywords: Children with Mental Retardation, Video Media Modeling, Toilet Training

\section{PENDAHULUAN}

Anak Berkebutuhan Khusus (ABK) di Indonesia mengalami kenaikan dengan jumlah anak tunagrahita menempati angka paling besar yaitu prevalensi diperkirakan 1-3\% dari penduduk Indonesia (Padila et al., 2020). Anak tunagrahita adalah anak berkebutuhan khusus dengan kemampuan kurang serta memiliki hambatan dalam proses tumbuh kembang (Kemenkes, 2017). Faktor-faktor yang mempengaruhi tumbuh kembang anak diantaranya adalah genetik (bawaan) dan faktor biologis (fisik dan kemampuan intelektual) (Panzilion et al., 2020).

Anak tunagrahita memiliki perkembangan dengan ciri kemampuan intelektual di bawah rata-rata anak yang normal (Panzilion et al., 2021; Padila et al., 2021). Salah satu hambatan tersebut adalah ketidakmampuan merawat dirinya sendiri atau Activities Daily Living (ADL) yang diantaranya toilet training. Dampak kegagalan toilet training mengakibatkan anak menarik diri/isolasi diri, sembelit, disfungsi berkemih, infeksi saluran kemih, tidak mampu menahan BAK ketika tidur, serta tidak memiliki sikap 
tanggung jawab. Pada akhirnya anak dengan kegagalan toilet training, bisa berdampak pada kualitas hidup yang tidak produktif (Sutherland et al., 2018).

Toilet training merupakan tugas perkembangan pada anak yang membutuhkan persiapan fisik, psikologis, maupun intelektual. Pembelajaran toilet training pada tunagrahita memerlukan waktu yang relatif lama. Kemampuan intelektual yang rendah, serta lemahnya dalam berfikir hal yang bersifat abstrak menyebabkan pencapaian tujuan pembelajaran yang kurang optimal (Fatmawati et al., 2020). Modeling media video dapat menarik minat dan fokus anak untuk menonton video yang disajikan. Anak terlihat senang, dan antusias dalam memperhatikan setiap adegan atau keterampilan toilet training yang diperagakan oleh model dalam video tersebut. Dengan modeling media video akan membantu merubah kemampuan toilet training anak dari tidak mampu menjadi mampu. Melatih anak dengan menggunakan modeling media video merupakan media yang berpengaruh terhadap kemampuan toilet training anak.

Penggunaan dan pengadaan media saat pembelajaran sangat mempermudah dalam memahami, yang bersifat abstrak menjadi konkrit. Media yang digunakan mengenai toilet training dapat menggunakan media audio visual. Kemampuan berfikir rendah anak tunagrahita menjadi alasan perlunya metode lebih menarik dan mudah dipahami. Pembelajaran toilet training untuk anak tunagrahita dimaksudkan sebagai bekal dikemudian hari serta anak tunagahita mandiri dalam menggunakan toilet (Kuo et al., 2019).

Studipendahuluan di SLB didapatkan bahwa 80\% dari 30 anak merupakan anak tunagrahita dan sisanya anak berkebutuhan khusus lainnya. Lebih dari 50\% anak tunagrahita memiliki hambatan toilet training, ditandai ada anak yang melakukan BAK dan BAB sembarangan serta tidak mampu menunjukan tanda keinginan untuk BAK dan BAB. Penelitian tentang media pembelajaran sudah pernah dilakukan, namun fokus pada penelitian ini adalah penggunaan video menggunakan animasi sehingga bisa meningkatkan minat anak tungrahita dalam pembelajaran toilet training.

\section{METODE PENELITIAN}

Waktu penelitian dilakukan pada bulan Mei-Juli 2021 di SLB Ciamis. Penelitian menggunakan rancangan pre-experiment dengan pendekatan one-group pretest posttest design. Populasi yaitu 32 anak tunagrahita yang diambil berdasarkan kriteria inklusi dan eklusi. Pengambilan sampel menggunakan metode purposive sampling.

Pengolahan data menggunakan uji Wilcoxon dengan bantunan komputerisasi. Instrumen penelitian yang digunakan yaitu lembar kuesioner mengenai toilet training yang dibuat dengan 10 pertanyaan yang sebelumnya telah dilakukan uji validitas. Penelitian ini telah mendapatkan laik etik (ethical clearance) dari komite yang berwenang.

\section{HASIL PENELITIAN}

Tabel. 1

Distribusi Frekuensi Anak Tunagrahita Berdasarkan Jenis Kelamin

\begin{tabular}{ccc}
\hline Jenis Kelamin & $\begin{array}{c}\text { Frekuensi } \\
\text { (Responden) }\end{array}$ & $\begin{array}{c}\text { Persentase } \\
(\%)\end{array}$ \\
\hline Laki-laki & 21 & 65,6 \\
Perempuan & 11 & 34,4 \\
\hline Jumlah & 32 & 100.0 \\
\hline
\end{tabular}


Berdasarkan tabel 1 menunjukan bahwa dari 32 responden dengan karakteristik anak tunagrahita berdasarkan jenis kelamin lebih banyak berada pada laki-laki yaitu berjumlah 21 responden $(65,6 \%)$.

Tabel. 2

Distribusi Frekuensi Anak Tunagrahita

Berdasarkan Pendidikan Orang tua

\begin{tabular}{ccc}
\hline Pendidikan Orang tua & $\begin{array}{c}\text { Frekuensi } \\
\text { (Responden) }\end{array}$ & $\begin{array}{c}\text { Persentase } \\
(\%)\end{array}$ \\
\hline Tidak Sekolah & 4 & 12,5 \\
Dasar & 15 & 46,9 \\
Menengah & 12 & 37,7 \\
Tinggi & 1 & 3,1 \\
\hline Total & 32 & 100 \\
\hline
\end{tabular}

Berdasarkan tabel 2 diketahui bahwa dari 32 responden dengan frekuensi tingkat pendidikan orang tua yang lebih tinggi yaitu pendidikan dasar sebanyak 15 responden $(46,9 \%)$.

Tabel. 3

Distribusi Frekuensi Anak Tunagrahita

Berdasarkan Pekerjaan Orang tua

\begin{tabular}{ccc}
\hline Pekerjaan orang tua & $\begin{array}{c}\text { Frekuensi } \\
\text { (responden) }\end{array}$ & $\begin{array}{c}\text { Persentase } \\
(\%)\end{array}$ \\
\hline Buruh & 12 & 37,5 \\
Petani & 9 & 28,1 \\
PNS & 1 & 3,1 \\
Wiraswasta & 6 & 18,8 \\
Pedagang kecil & 3 & 9,4 \\
Lainnya & 1 & 3,1 \\
\hline Jumlah & 32 & 100.0
\end{tabular}

Berdasarkan tabel 3 diketahui bahwa dari 32 responden dengan frekuensi karakteristik pekerjaan orang tua yang lebih tinggi yaitu bekerja sebagai buruh sebanyak 12 responden $(37,5 \%)$.

Tabel. 4

Distribusi Frekuensi Karakteristik Responden

Berdasarkan Pendapatan Keluarga

\begin{tabular}{lcc}
\hline \multicolumn{1}{c}{ Pendapatan Keluarga } & $\begin{array}{c}\text { Frekuensi } \\
\text { (responden) }\end{array}$ & $\begin{array}{c}\text { Persentase } \\
(\%)\end{array}$ \\
\hline Kurang & 29 & 90,6 \\
Menengah & 2 & 6,3 \\
Tinggi & 1 & 3,1 \\
\hline Jumlah & 32 & 100 \\
\hline
\end{tabular}

Berdasarkan tabel 4 diketahui bahwa dari 32 responden dengan frekuensi karakteristik pendapatan keluarga yang lebih tinggi berada pada tingkat ekonomi kurang sebanyak 29 responden $(90,6 \%)$. 
Tabel. 5

Distribusi Frekuensi Tingkat Kemampuan Toilet Training Sebelum dan Sesudah Diberikan Modeling Media Video

\begin{tabular}{llcccccc}
\hline \multirow{2}{*}{ No } & \multirow{2}{*}{ Kategori } & \multicolumn{3}{c}{ Pretest } & \multicolumn{3}{c}{ Posttest } \\
\cline { 2 - 8 } & & $\mathrm{F}$ & $\%$ & Mean & $\mathrm{f}$ & $\%$ & Mean \\
\hline 1. & Baik & 11 & 34,4 & & 22 & 68,8 & \\
2. & Cukup & 17 & 53,1 & 6,88 & 10 & 31,2 & 8,47 \\
3. & Kurang & 4 & 12,5 & & 0 & 0 & \\
\hline & Jumlah & 32 & 100.0 & & 32 & 100.0 & \\
\hline
\end{tabular}

Berdasarkan tabel 5 diketahui bahwa tingkat kemampuan toilet training sebelum diberikan intervensi modeling media video toilet training (pretest) berada pada kategori baik sebanyak 11 responden $(34,4 \%)$, kategori cukup sebanyak 17 responden $(53,1 \%)$ dan kategori kurang sebanyak 4 responden $(12,5 \%)$. Sedangkan setelah diberikan intervensi modeling media video toilet training (posttest), kemampuan toilet training meningkat, pada kategori baik sebanyak 22 responden $(68,8 \%)$, kategori cukup sebanyak 10 responden $(31,2 \%)$ dan tidak ada responden pada kategori kurang. Hasil rata-rata nilai pretest sebesar 6,88 dan posttest 8,47 .

Tabel. 6

Hasil Uji Beda Tingkat Tingkat Kemampuan Toilet Training Sebelum dan Sesudah Diberikan Modeling Media Video Menggunakan Uji Wilcoxon

\begin{tabular}{lccc}
\hline & $\mathrm{N}$ & $\begin{array}{c}\text { Persentasi } \\
(\%)\end{array}$ & $p$ Value \\
\hline Menurun & 0 & 0 & 0.000 \\
Meningkat & 28 & 87,5 & \\
Tetap & 4 & 12,5 & \\
\hline Jumlah & 32 & 100.0 & \\
\hline
\end{tabular}

Berdasarkan tabel 6 menunjukkan bahwa 28 responden mengalami peningkatan kemampuan toilet training dan 4 responden dengan tingkat kemampuan toilet training tetap. Nilai tersebut menandakan bahwa nilai posttest lebih besar dari pada pretest dengan peningkatan rata-rata sebesar 1,59. Hasil uji Wilcoxon didapatkan $p$ value sebesar 0,000 maka $<\alpha=0,05$ jadi dapat disimpulkan bahwa terdapat pengaruh modeling media video terhadap tingkat kemampuan toilet training anak tunagrahita.

\section{PEMBAHASAN}

Tabel 1 dapat diketahui bahwa sebagian besar responden berjenis kelamin lakilaki sebanyak 21 repsonden. Pada pelaksanaan toilet training, kematangan sosial merupakan salah satu aspek yang mendukung. Menurut hasil penelitian Dewi \& Argadireja (2019) salah satu faktor yang mempengaruhi kematangan sosial adalah usia dan jenis kelamin, dimana anak laki-laki cenderung lebih lamban dalam urusan toilet training.

Tabel 2 dapat diketahui bahwa sebagian besar pendidikan orangtua responden pada kategori pendidikan dasar sebanyak 15 responden. Menurut Lestari (2018) tingkat pendidikan ibu turut menentukan mudah tidaknya seseorang menyerap dan memahami pengetahuan yang mereka peroleh dari kepentingan keluarga. Pendidikan itu sendiri amat diperlukan seseorang lebih tanggap adanya masalah perkembangan anak salah satunya penerapan toilet training didalam keluarganya. Tingkat pendidikan akan 
berkorelasi dengan tingkat pengetahuan. Dimana ibu yang memiliki pengetahuan yang baik tentang toilet training akan berdampak pada cepatnya ibu melatih toilet training secara dini, hal ini berdampak positif bagi ibu maupun anak yaitu anak dapat mandiri melakukan toilet training.

Tabel 3 dapat diketahui bahwa sebagian besar pekerjaan orangtua responden pada kategori buruh sebanyak 12 responden. Sedangkan tabel 4 dapat diketahui bahwa sebagian besar pendapatan orangtua responden pada kategori kurang sebanyak 29 responden. Hasil tabel 3 dan tabel 4 memperlihatkan kondisi ekonomi orangtua responden. Ekonomi orang tua yang baik dapat memberikan fasilitas yang memadai dalam menunjang kebutuhan anak dalam melakukan toilet training (Rahayu, 2021).

Tabel 5 menunjukan bahwa tingkat kemampuan toilet training anak tunagrahita sebelum diberikan intervensi modeling media video terhadap 32 responden didapatkan hasil sebagian besar masuk dalam kategori cukup. Setelah diberikan intervensi modeling media video tingkat kemampuan toilet training sebagian besar pada kategori baik. Penelitian ini sejalan dengan Alvionita et al., (2019) bahwa terdapat kenaikan dalam kemampuan toilet training responden setelah diberikan pelatihan. Hasil menunjukan adanya perkembangan kemampuan toilet training pada anak tunagrahita setelah menonton modeling media video. Didukung oleh penelitian Kuo et al., (2019) bahwa modeling media video dapat menarik minat dan fokus anak untuk menonton video yang atau keterampilan toilet training yang diperagakan oleh model dalam video tersebut. Sejalan dengan pernyataan Wiana (2018) yang mengungkapkan bahwa "Media in learning has a function as a tool to clarify the message conveyed by the teacher". Hal ini dapat di simpulkan bahwa media merupakan alat untuk memperjelas pembelajaran.

Menurut Febriani \& Irdamurni (2019) penggunaan dan pengadaan media saat pembelajaran sangat mempermudah siswa dalam memahami materi pelajaran, yaitu materi yang bersifat abstrak menjadi konkrit. Didukung Fahrurozi et al., (2017) bahwa multimedia digunakan untuk membuat pelajaran lebih menarik dan pada saat yang sama memberikan siswa dengan contoh nyata tentang cara kerja multimedia. Walaupun tidak sepenuhnya responden dapat melakukan sendiri, akan tetapi ada perubahan menuju kearah positif dalam meningkatkan kemampuan anak. Menurut Parulian et al., (2020) kemampuan anak dipengaruhi beberapa faktor diantaranya yaitu minat anak, pengalaman anak, lingkungan anak, dan pengembangan kemampuan anak. Toilet training dikatakan berhasil apabila tahapan toilet training dapat terpenuhi atau diketahui anak seperti menyampaikan keinginan BAK atau BAB, melepas dan memakai celananya sendiri, membersihkan diri sendiri, menyiram dan memcuci tangan setelah BAK dan BAB.

Penelitian ini selaras dengan penelitian Aziz (2018) dengan p-value 0.000 dimana menunjukkan kekuatan tingkat hubungan korelasi adanya pengaruh modelling media video terhadap peningkatan kemampuan toilet training pada anak retardasi mental. Hal ini juga didukung oleh penelitian Saragih \& Andayani (2019) yang menunjukkan kekuatan tingkat hubungan korelasi adanya hubungan dukungan keluarga dengan kemampuan keterampilan sosial yang dimiliki anak tunarungu. Kesimpulan dari hasil penelitian ini yaitu bahwa kemampuan toilet training anak tunagrahita dalam penelitian ini meningkat setelah diberikan perlakuan penayangan modeling media video artinya ada pengaruh modeling media video terhadap kemampuan toilet training anak tunagrahita menggunakan uji wichoxon nilai $p$-Value 0,001 . 


\section{SIMPULAN}

Terdapat pengaruh modeling media video terhadap kemampuan toilet training anak tunagrahita.

\section{SARAN}

Hasil penelitian ini diharapkan bermanfaat bagi guru SLB dan orang tua dengan anak berkebutuhan khusus sehingga kemampuan toilet training bisa lebih optimal. Untuk saran pengembangan lebih lanjut, diperlukan penelitian kualitatif dengan menambahkan dukungan keluarga dalam pelaksanaan toilet training.

\section{UCAPAN TERIMA KASIH}

Peneliti haturkan rasa syukur kepada Allah Subhanahu Wa Ta'ala, karena dengan kemudahan yang diberikan sehingga penelitian ini bisa berjalan dengan lancar. Penelitian ini dapat terlaksana dengan baik atas pendanaan penuh dari Kemenristek/BRIN. Serta dukungan dari (1) Ketua STIKes Muhammadiyah Ciamis (2) LPPM STIKes Muhammadiyah Ciamis (3) Ketua Program Studi S1 Keperawatan (4) Kepala Sekolah beserta Guru SLB Ciamis. Semoga Alloh Subhanahu Wa Ta'ala membalas dengan kebaikan yang setimpal. Aamiin.

\section{DAFTAR PUSTAKA}

Alvionita, N., Lestari, L., Nurfianti, A. (2019). Efektivitas Metode Belajar Picture and Picture terhadap Keterampilan Toilet Training : Bak pada Anak dengan Gangguan Autism Spectrum Disorder (ASD) Usia 5-7 Tahun di Poli Anak Berkebutuhan Khusus Rsjd Sungai Bangkong Provinsi Kalimantan Barat. Jurnal Proners, 4(1), 2-12. https://jurnal.untan.ac.id/index.php/jmkeperawatanFK/article/view/34336

Aziz, A. (2018). Pengaruh Video Animasi terhadap Kemampuan Bina Diri Anak Tunagrahita Ringan pada Pembelajaran Bina Diri di SLB Tunas Kasih Surabaya. Jurnal Pendidikan Khusus, 1-21. Retrieved from https://jurnalmahasiswa.unesa.ac.id/index.php/jurnal-pendidikankhusus/article/download/23731/21693

Dewi, A. F., \& Argadireja, D. S. (2019). Hubungan Usia dan Jenis Kelamin dengan Kematangan Sosial pada Anak Tunagrahita di SLBN-A Citeureup Kota Cimahi. Prosiding Pendidikan Kedokteran, 7(1). 1-4. http://karyailmiah.unisba.ac.id/index.php/dokter/article/view/26700

Fahrurozi, S. K., Maryono, D., \& Budiyanto, C. W. (2017). The Development of Video Learning to Deliver a Basic Algorithm Learning. IJIE (Indonesian Journal of Informatics Education), 1(1), 135. https://doi.org/10.20961/ijie.v1i2.12446

Fatmawati, K., Arief, Y. S., \& Kurnia, I. D. (2020). The Effect of Animation Video Modeling on Mother's Ability in Preparing Toilet Training in Toddler. EurAsian Journal of BioSciences, 14(1), 1575-1581. http://www.ejobios.org/article/theeffect-of-animation-video-modeling-on-mothers-ability-in-preparing-toilettraining-in-toddler-7669

Febriani, S., \& Irdamurni, I. (2019). Video Tutorial Dapat Meningkatkan Keterampilan Menggosok Gigi Anak Tunagrahita Kategori Sedang. Ranah Research, 1(4), 991997. https://jurnal.ranahresearch.com/index.php/R2J/article/view/161

Kemenkes. (2017). Profil Kesehatan Indonesia Tahun 2017. Jakarta. https://pusdatin.kemkes.go.id/resources/download/pusdatin/profil-kesehatanindonesia/Profil-Kesehatan-Indonesia-tahun-2017.pdf 
Kuo, C. C., Tseng, Y. C., Chang, C. F., Chen, C. S., Li, Y. J., \& Wang, H. T. (2019). Using Video Modeling Package on Improving Workplace Social Skills of Young Adults with Talent Traits and Autism: A Case Study. Universal Journal of Educational Research, 7(12), 2806-2816. https://doi.org/10.13189/ujer.2019.071231

Lestari, F. P. (2018). Kontribusi Pola Asuh Orangtua terhadap Self Care Skill Anak Tunagrahita di SDLB/C Alpa Kumara Wardhana II Surabaya. Jurnal Pendidikan Khusus, 1-16. https://ejournal.unesa.ac.id/index.php/jurnal-pendidikankhusus/article/view/24397/22323

Padila, P., Setiawati, S., Inayah, I., Mediani, H., \& Suryaningsih, C. (2020). Emosi dan Hubungan Antar Sebaya pada Anak Tunalaras Usia Sekolah antara Terapi Musik Klasik (Mozart) dan Murrotal (Surah Ar-Rahman). Jurnal Keperawatan Silampari, 3(2), 752-763. https://doi.org/10.31539/jks.v3i2.1276

Padila, P., Harsismanto, J., Andrianto, M, B., Sartika, A., \& Ningrum, D, S. (2021). Pengalaman Orangtua dalam Merawat Anak Retardasi Mental. Jurnal Kesmas Asclepius, 3(1), 9-16. https://doi.org/10.31539/jka.v3i1.2163

Panzilion, P., Padila, P., Tria, G., Amin, M., \& Andri, J. (2020). Perkembangan Motorik Prasekolah antara Intervensi Brain Gym dengan Puzzle. Jurnal Keperawatan Silampari, 3(2), 510-519. https://doi.org/10.31539/jks.v3i2.1120

Panzilion, P., Padila, P., Setyawati, A, D., Harsismanto, J., \& Sartika, A. (2020). Stimulation of Preschool Motor Development Through Brain Gym and Puzzle. JOSING: Journal of Nursing and Health, 1(1), 10-17. https://doi.org/ 10.31539/ josing.v1i1.1166

Panzilion, P., Padila, P., \& Andri, J. (2021). Intervention of Numbers Puzzle Against Short Memory Mental Retardated Children. JOSING: Journal of Nursing and Health, 1(2), 41-47. https://doi.org/10.31539/josing.v1i2.2332

Parulian, K. R., Supriyanti, S. I., \& Supardi, S. (2020). Hubungan Karakteristik Anak, Dukungan Keluarga Dengan Kemandirian Personal Hygiene Anak Tunagrahita. ejournal, 2(2), 177-188. http://ejournal.stiksintcarolus.ac.id/index.php/CJON/article/view/42

Rahayu, S. F. (2021). Relationship Pattern Of Working Parents To The Independence Of Toilet Training Pre School Children (Literature Study). Healty-Mu Journal, 4(2), 82-87. https://journal.mbunivpress.or.id/index.php/healthy/article/view/27

Saragih, A. A., \& Andayani, B. (2019). Buku Panduan Aman untuk Mengajarkan Keterampilan Bina Diri Berpakaian pada Anak Tunagrahita. Gadjah Mada Journal of Professional Psychology (GamaJPP), 5(2), 173. https://doi.org/10.22146/gamajpp.49957

Sutherland, J., Carnett, A., Van-Der-Meer, L., Waddington, H., Bravo, A., \& McLay, L. (2018). Intensive Toilet Training Targeting Defecation for a Child with Autism Spectrum Disorder. Research and Practice in Intellectual and Developmental Disabilities, 5(1), 87-97. https://doi.org/10.1080/23297018.2017.1360153

Wiana, W. (2018). Interactive Multimedia-Based Animation: A Study of Effectiveness on Fashion Design Technology Learning. Journal of Physics: Conference Series, 953(1). https://doi.org/10.1088/1742-6596/953/1/012024 